\title{
Trade Liberalization-Trade Revenue Nexus: An Empirical Enquiry of Trade Laffer Curve of Pakistan
}

\begin{abstract}
Khalil Ahmad ${ }^{1 *}$, Safdar Ali $^{1}$
Abstract

This study tries to explore the trade revenue implication of trade liberalization for Pakistan. Laffer curve approach is used to see the non-linear relationship between trade openness and trade tax revenue. Empirical evidence shows that trade openness has constructive impact on trade tax revenue in linear term. The non-linear relationship has also been explored in the presence of other macroeconomic variables. The marginal impact of non-liner squire trade liberalization has adverse effect on trade tax revenue. In the long run, the empirical investigation proves the existence of inverted U-shaped behavior between trade liberalization and trade tax revenue in Pakistan but this behavior does not exist in short run.
\end{abstract}

Keywords: Trade Liberalization, Trade Revenue, Co-integration.

JEL Classification: F10, F13, C13.

\section{Introduction}

Twenty-first century came with the phenomenon of globalization or economic integration. In such environment, all industrial and developing economies opened their borders for trade in goods and services. It has also been accepted that trade liberalization improves economic efficiency and spurs economic growth through spillover effects (Krueger, 1997) and (Edwards, 1992). While in the case of developing economies, trade liberalization has inconclusive results (Rodríguez \& Rodrik, 2001). Most of the developing economies protect their imperfect sector from the global competition by a variety of tariff and nontariff restrictions. The main reason of protection is strengthening the domestic infant industries and acquiring the revenue through trade barriers.

Trade Openness may create fiscal uncertainty in case of developing economies because of major share of trade tax in total tax collection. During liberalization, it is fundamental for developing countries to draw trade policy properly for generation of trade revenue. Stotsky, Ebrill, and Gropp (1999) concludes that any loss of trade revenue may create the importance of the fiscal implication of trade liberalization. International Monetary Fund (IMF) described that the share of trade revenue has been increased in most of the developing countries after the implementation of Structural Adjustment Program

${ }^{1}$ Higher Education Department, Government of Punjab, Pakistan

* Corresponding Author: khalilahmad122@gmail.com 
(SAP). For example in African countries, the share of trade revenue is 30.5 percent of total revenue. However, if we look at the Organization for Economic Cooperation and Development (OECD) countries, the share of trade revenue was only 0.8 percent in total revenue. M. Keen and Ligthart (2005) argued that developed countries have so many other heads of revenue collection to overcome the trade revenue loss. The low income countries have no more capacity to improve their fiscal condition during liberalization. Therefore, developing economies are more in need of trade revenue to meet their fiscal needs (Stotsky et al., 1999). Further, cut in tariff rate will cause to reduce trade revenue (Khattry \& Rao, 2002).

Trade liberalization has dual effect on trade revenue for different economies, regions and different data sets. Trade liberalization has negative impact on trade revenue due to reduction in tariff rate. In some cases, trade liberalization has positive impact on trade revenue due to increase in the volume of imports and vice versa. This effect is demonstrated by a "Trade Laffer Curve" that explains the relationship between tariff rates and trade revenue. When tariff rate is high, it reduces the trade tax revenue due to reduction in imports volume. On the contrary, the lower tariff rate may also reduce the tax revenue from trade openness. When any country has already relatively liberalized, additional discounts in tariff rate will not be the source of any addition in trade revenue.

According to Tanzi (1989) tax revenue as a share of GDP remains low in most of the developing countries. The contribution of regressive taxes is low as compared to progressive taxes due to three reasons: (i) Complete absence of agricultural income tax, (ii) High exemption limits as compared to levels of per capita income and (iii) Widespread tax evasion. In Pakistan, high share of total tax collection is produced through regressive taxes. Import duties produce more than 40 percent of total government revenue. A decline in tariff rate is likely to diminish the proportion of total public revenue. This may increase the burden on government in the form of budget deficit. However, to some extent, the government can overcome the gap through tax reforms i.e. value added tax. For example, reduction in import duty must be accompanied with the restriction and proper monitoring of Afghan Transit Trade. More imports and exports should come in trade volume through the legal channel. This generates high trade revenue for the government. Furthermore, government can enhance the revenue share by introducing value added tax (VAT), broad based sales tax and agriculture income tax.

After SAP reforms, tax revenue as a proportion of GDP in Pakistan started deteriorating. Within the kind of indirect taxes, import duties are used to provide the largest share in revenue for the government. Pakistan has already made significant adjustments in its tax system after structural reforms like broad based sale tax (value added tax). Now government has less reliance on import duties to fill the fiscal needs. Imports duties only accounted for 8 percent of total government revenue in 2002, as compared with 29

Sukkur IBA Journal of Management and Business - SIJMB | Volume 5 No. 1 January - June 2018 @ Sukkur IBA University 
percent in 1992 (Zaidi, 2005). Pakistan's trade patterns and trade policy have continuously been moving towards fewer and fewer control, lower tariffs, and more openness. Non-tariff barriers have been replaced by tariff, and tariff rates have come tumbling down. After the SAP, country moves towards fast liberalization with exports -led growth strategy but unfortunately supply sides inactive for exports (such as prices, inputs, tax incentives) do not be helpful in promotion of exports. In the current condition revenue collection has been changed. One of the most significant changes in Pakistan's economy is the result of lowering tariffs and overall reduction in trade revenue.

Pakistan's fiscal performance is characterized with a number of macroeconomic variables. On the revenue side, the tax-to-GDP ratio shows a declining trend over the last forty years. Overall fiscal effort of the economy has not been satisfactory. Taxto-GDP ratio remained more or less stagnant at 15 to 16 percent during the last four decades. Pakistan mostly generates its revenue through trade tax which may cause fiscal instability because it has been considerably liberalizing its borders during the last twenty years. The emphasis of present study is to investigate the fiscal implication of trade liberalization in Pakistan. Furthermore, this study uses Laffer curve approach to provide the desirable result of trade tax revenue and trade liberalization. Trade liberalization has negative impact on trade revenue due to reduction in tariff rate. In some cases, trade liberalization has positive impact on trade revenue due to increase in the volume of imports and vice versa. This effect is demonstrated by a "Trade Laffer Curve" that explains the relationship between tariff rates and trade revenue.

\section{Literature Review}

Economics literature presents a variety of views regarding economic, political, social and fiscal implication of trade liberalization. On one hand, it is viewed as an important engine of economic growth and on the other hand, it may have negative consequences for developing countries. J. Bhagwati (2004), for example, sees globalization as the cause of community problems, such as poverty, macroeconomic imbalances and environmental loss at worldwide. Bevan (1995) analyses the influence of trade openness on macroeconomic variables for the developed and developing countries. He concluded that there exist inverse relationships between liberalization and more economic instability. In this context, J. N. Bhagwati (2004) and Bacha (1990) analyzed the association between trade openness and macroeconomic fluctuation and established that tradeoff behavior between trade openness and macroeconomic volatility is reason of fiscal instability. Yap (1997) uses three gaps model (saving, fiscal and foreign exchange gaps) to see the impact of tariff reduction on macroeconomics activity in case of Philippines. He explored that trade liberalization is cause to fill the fiscal and trade deficit gaps.

(Negishi (1972)) developed a theoretical model for industrial protection. In the light of different types of assumptions, a newly born industry cannot compete with foreign

Sukkur IBA Journal of Management and Business - SIJMB | Volume 5 No. 1 January - June 2018 @ Sukkur IBA University 
market because of its high cost of production. However, if it gains a long term technological progress through learning process it may be able to reduce its average cost. He argued that downward shift of cost curve may create comparative advantage for newly born industry and produce more profit in future from free trade. While, in the case of developed and developing countries used commercial policy to protect their home market from the foreign competition. For example, China and Korea used highly protectionist policy against free trade in 1970s. These trade restrictions seem to protect the domestic market from the foreign competition and may generate revenue to overcome the trade externalities (Krugman, 1986). Trade taxes may increase the domestic revenue, if country increases the rate of trade taxes or volume of trade. Most of the developing economies depend on the trade tax revenue to meet their fiscal needs.

According to Melvin (1970), the public sector with imperfect administrative capacity, high corruption and a narrow tax base, tends to accumulate more share of revenue from those areas which are easy to tax or less collection cost. For example, imports duties have a lowest quantity of tax evasion. While, in the case of those countries which have high budget constraint bears high distortionary per unit cost to trade tax collection. Further cuts in trade tax may be serious loss for revenue collection (Anderson, 1998). This arises the question whether there is existence of any relationships between tariff liberalization and fiscal condition It may be, when tariff liberalization is correctly administered, overcome the corruption and tax evasion but in itself has no causality between trade openness and trade tax. In general, most countries shifted towards a replica whereby a government's need on non-trade tax as the most important basis of revenue as compared to trade tax. The most common examples include, income, corporate, excise, value added tax (VAT), social-security, property and resource taxes (Melvin, 1975).

Trade openness and trade revenue has no clear association with domestic tax collection. The previous studies suggest different factors such as share of trade tax revenue, composition and tax structure of the economy and administration abilities have significant consequence on tax revenue (Stotsky et al., 1999) and (M. Keen \& Ligthart, 2002). Furthermore, for the Sub-Saharan African countries Adam, Bevan, and Chambas (2001) analyse the link between exchange rate and domestic taxes. They found inverse association between exchange rate and revenue of taxes. Pupongsak (2010) investigated the association between trade liberalization and tax for Thai economy. The result of this research is that free trade inversely related with the tax revenue. Due to trade liberalization put a pressure on Thai fiscal policy. The trade liberalization provides maximum advantages to those economies that are more efficient in their fiscal conditions. While in some cases fiscal adjustment is much difficult to further cut in tariff rate. most of the developing countries are not well aware of opportunities linked with open market.

Sukkur IBA Journal of Management and Business - SIJMB | Volume 5 No. 1 January - June 2018 @ Sukkur IBA University 
Tanzi (1989) explores so many factors they are affecting free trade tax revenue for developed and developing nations. Important factors are prices, fiscal imbalances, rates of exchange and local taxes revenue. The results describe that the rate of exchange, CPI, and fiscal policy are inversely related with trade taxes. Agbeyegbe, Stotsky, and WoldeMariam (2006) analyzed that trade revenue is determined by the elasticity of price for the import demand condition and the elasticity of price for the supply of substitution for imported goods. If the imports demand behavior of a country is price elastic, the revenue gains through free trade. Aliyu (2007) empirically verified the factors of import and export demand behaviors for Nigerian economy. He establishes that income has slightly affected the imports and exports while previous income level highly affected export demand. In case of Pakistan the imports are less elastic with prices and more elastic with income. It implies that increase in tariff rate will result increase in trade revenue through trade liberalization.

Most of the developing economies heavily depend on the trade tax revenue to meet their budget deficit. These economies use the trade liberalization policy due to lack of resources to meet the domestic expenditures (M. Keen \& Ligthart, 2002). If developing economies reduce the level of trade restriction, this may cause increase in total imports of those countries and also reduce the tax revenue from the importing countries. It may increase the budget deficit of the government and government has to increase other sources of internal taxes to compensate budget deficit.

Kowalski (2005) examines relationship between trade openness and revenue for 12 nations and establishes that in most cases the likely-trade revenue drops are relatively less in the development of liberalization. The trade liberalization provides maximum advantages to those economies that are more efficient in their fiscal scenario. While in some cases fiscal adjustment is much difficult to further cut in tariff rate because most of the developing countries are aware of opportunities linked with open market. While, some researcher have also pointed out the potential tariff or trade revenue loss as a main difficulty to reducing their tariffs levels, without a favorable changes in the tax structure (Stotsky et al., 1999).

Rajaram (1992) explains that Pakistani government is not well aware of tariff structure by WTO and inadequate consideration was paid to the revenue and liberalization of trade effects. This shows that reforms of tariff should be restored for reducing the loss of tariff revenue. So before making any tariff reforms the government of Pakistan should strictly concern the revenue by the tariff and the trade liberalization process of WTO. Adam et al. (2001) empirically investigated that the high share of trade revenue may cause to further reduction in domestic regressive taxes. This proposes that liberalization of trade and revenue of taxes are responsive to measurement issues. Similarly, Agbeyegbe et al. (2006) did not find robust association between trade liberalization and trade revenue. M. Keen and Ligthart (2002) suggests that policy of

Sukkur IBA Journal of Management and Business - SIJMB | Volume 5 No. 1 January - June 2018 @ Sukkur IBA University 
increasing domestic consumption taxes at least equal with tariff cuts has equal compensation gained domestic consumers due to trade openness. Trade openness increases the real income of the consumer through the reduction in world prices of goods and services. Furthermore, trade openness increases the efficiency of production, improves the tariff reforms and increase revenue of trade for the government. Aizenman and Jinjarak (2009) also look to be hold by the work of (M. M. Keen \& Baunsgaard, 2005). Trade liberalization is a process of removable of tariff rate cause to trade revenue loss behavior is unclear because the trade revenue is not only dependent on level of openness intensity of trade as well as domestic revenue structure, plus the tax system efficiency and tax collection administrative cost and capacity (M. Keen \& Ligthart, 2002; Stotsky et al., 1999).

Hisali (2012) investigated the trade revenue behavior for Uganda using time series data. The results support that exchange rate negative impact on custom revenue. Higher impart price may cause to reduce trade volume as well as trade revenue in the long run. Spearot (2013) investigated the relationship between trade revenue and imports demand, imports prices and imports demand elasticity. The empirical results show that less elastic imports produced more trade revenue as compared to more elastic demand for imports during trade liberalization. Epaphra (2014) empirically examined how trade liberalization influenced the import duty revenue and domestic tax conditions in Tanzania? The empirical results showed that trade revenue as a share to GDP is positively linked with tariff rates. This implied that trade liberalization produced considerable loss of import duty revenue in Tanzania. Foreign exchange market also influenced the trade tax revenue. Depreciation of floating exchange rate had negative impact on trade tax revenue.

In the global context, ambiguity exists on the association between trade openness and trade tax revenue. According to theory, trade liberalization in the form of lower tariff rates cause to revenue loss. Trade liberalization may cause to improve the import volume, and hence the tax base as well as trade revenue, although to measure the effect of tariff removal on trade revenue is ambiguous. When we investigate the literature on the association of trade liberalization and trade taxes, no significant work has been done yet in this area. Even though, previous work investigated the determinants of trade revenue. While, some are based on the consequences of trade revenue for developed world. This issue gained more importance for developing world because these countries rapidly move towards trade liberalization without considering their fiscal conditions. When we review the literature on trade liberalization and trade revenue, we find hardly any study in detail for case of Pakistan. Some studies reflect macroeconomic determinant, component and composition of trade revenue and other reflect economic consequences independently. Pakistan is a good case study because it has more concentration towards liberalization without considering its revenue implications during the last twenty years.

Sukkur IBA Journal of Management and Business - SIJMB | Volume 5 No. 1 January - June 2018 @ Sukkur IBA University 


\section{Theoretical Background}

According to the theories of free trade, society's welfare level may be improved through perfect market conditions via different channels. However, liberalization may cause the social welfare loss due to decline in trade revenue. This revenue loss may bring fiscal deficit or the excessive burden of indirect taxes. Under these circumstances, free trade has two-fold effects on developing world. First, it may improve the economic wellbeing through spillover effects. Second, it may cause fiscal uncertainty due to trade revenue loss during liberalization. A large number of studies investigate its economic, socio-political and fiscal implications. Mill (1848) argued that commercial policy or free trade restrictions are necessary for promoting infant industries for competition. This suggests that poor countries should adopt the commercial policy to protect their resources from the foreign competition. Commercial policy is based on the following instruments: (i) tariff on import or tax (ii) quota system (iii) exchange control (iv) export subsidies and (v) voluntary export restraints. These trade restrictions seem to protect the domestic market from the foreign competition and may generate revenue. Trade taxes increase the revenue in both ways if country increases the level of trade taxes or volume of trade in term of units.

Trade liberalization has dual effect on trade revenue for different economies, regions and different data sets. Trade liberalization has negative impact on trade revenue due to reduction in tariff rate. In some cases, trade liberalization has positive impact on trade revenue due to increase in the volume of imports and vice versa. This effect is demonstrated by Ahmad and Chaudhary (2016) trade laffer curve that explains the relationship between tariff rates and trade revenue. When tariff rate is high, it reduces the trade tax revenue due to reduction in imports volume. On contrary, the lower tariff rate may also reduce the tax revenue from trade openness. When any country has already relatively liberalized, additional discounts in tariff rate will not be the source of any addition in trade revenue.

The graphical and functional presentation of tariff effect on partial equalibrium for a small country case has been presented by Feenstra (2015) and Salvatore (2013) as below 


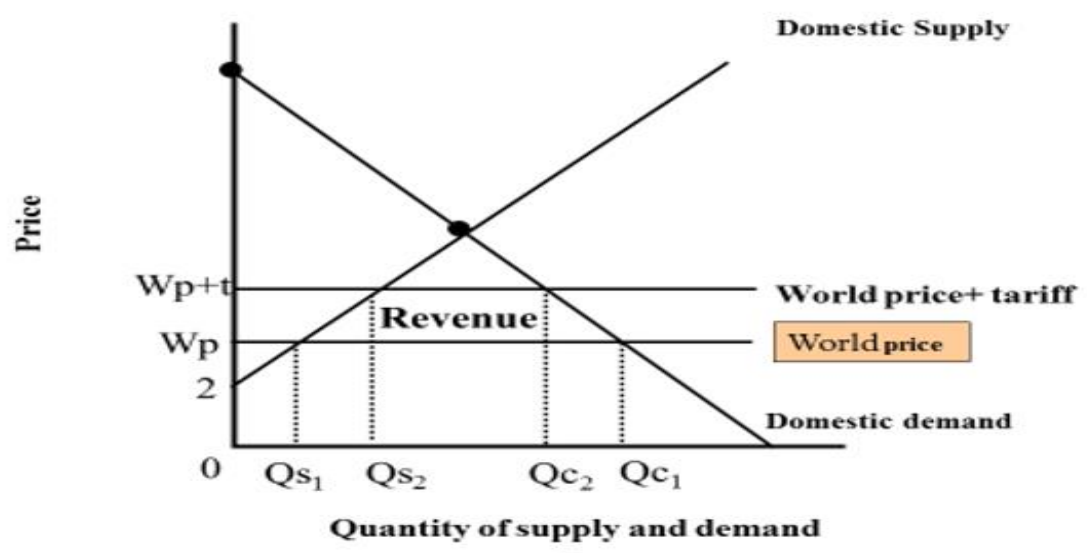

Figure 3.1: Partial Equilibrium Condition for Small country Case.

Before the imposition of tariff the quantities and price level are represented as follows:

$\mathrm{Q}_{\mathrm{s} 1}=$ Quantity of exports

$\mathrm{Q}_{\mathrm{cl}}=$ Quantity of imports.

$\mathrm{WP}=$ the world price level

$\mathrm{Q}=$ imports level $\left(\mathrm{Q}_{\mathrm{c} 1}-\mathrm{Q}_{\mathrm{s} 1}\right)$

After imposition of tariff, the price level and quantities are expressed as:

$\mathrm{wp}+\mathrm{t}=$ Domestic price level

$\mathrm{Q}_{\mathrm{s} 2}=$ Quantity of exports

$\mathrm{Q}_{\mathrm{c} 2}=$ Quantity of imports.

$\mathrm{Q}_{\mathrm{m}}=$ imports level $\left(\mathrm{Q}_{\mathrm{c} 2}-\mathrm{Q}_{\mathrm{s} 2}\right)$

When a country has less elastic import demand, increase in tariff rate causes to increase the trade revenue. Kenen (1985) presents a static model, which puts together the elasticity and absorption approaches to measure the Marshal Lerner (ML) condition. The ML condition implies that the countries having sum of price elasticities of import and export greater than one will have the more tax revenue from trade. But the price elasticity of import demand is not the sole determinant of trade revenue. There are several other determinants of trade revenue that are discused in the literature of internal economics. For example, M. Keen and Ligthart (2002) pointed out various variables like exchange rate, inflation, term of trade and political instability that affect trade revenue. This behavior has been shown in the following figure 3.2. 


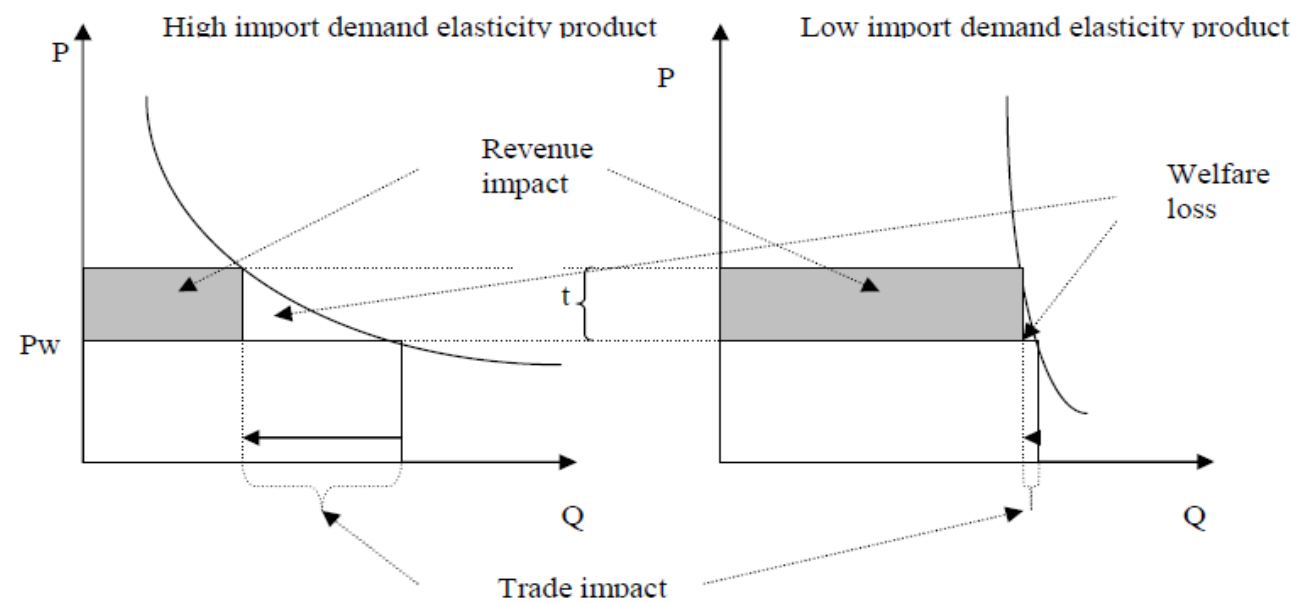

Part-A

Part-B

Where,

Figure 3.2: Price Elasticity of Imports and Trade Tax Revenue.

$\mathrm{P}=$ Price level

$\mathrm{Q}=$ Quantity of imports

$\mathrm{Pw}=$ World prices

$\mathrm{t}=$ Level of tariff

Figure 3.2 explains the trade revenue and welfare effects of trade liberalization for more and less imports demand behavior. Imposition of tariff in Part A, with more price elasticity of import demand yields less trade revenue with more welfare loss. While, on the other side of less imports demand produces more trade revenue with less welfare loss. Reduction in the tariff level produce reverse result discussed as above.

In economic theory, there are variety of views and strategies exist regarding tariff liberalization and tariff revenues. Haque and Mukherjee (2005) recommended that profit tax is more appropriate against tariff revenue loss as an alternative of commodity taxes especially in market economy. In monopoly condition, Mujumdar (2004) suggested that profit tax is a better options for government to make tariff revenue loss neutral against trade liberalization. On the other hand, Emran (2005) suggested that choosy import items tariff is used to generate revenues from tariff liberalization. The strategy is more beneficial for revenue generation as well as protect the production of these items. This strategy is more appropriate for developed nations because they have large trade volume of trade under the assumption of constant producer prices. Later on Naito (2006) studied the changing aspects of tariff liberalization and tax transformations under revenue a neutral stance. He concluded that tariff revenue is not recoverable in developing economies because these economies have larger share of imports in capital

Sukkur IBA Journal of Management and Business - SIJMB | Volume 5 No. 1 January - June 2018 @ Sukkur IBA University 
goods rather than consumer goods. So, these strategies are not applicable for making tariff revenue loss against tariff liberalization for developing world.

Tax system and tax rate play a very important role to maximize the welfare in a free as well as in mixed economic system. In the capitalist economic system private sector is more important to create the economic efficiency. In Keynesian economic system

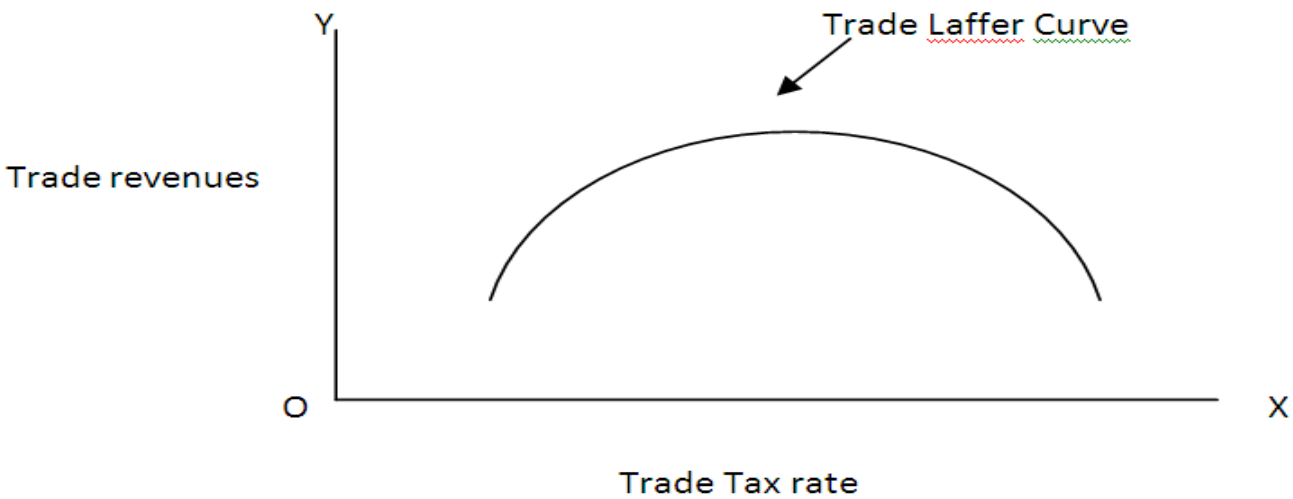

Figure 3.3: Trade Tax and Trade Revenue.

public sector is more important to stimulate economic and social efficiency. In free market economic system high tax rate leads to discourage social efficiency. This is an old issue in economic theory, what is the optimal tax rate in economies (Laffer, 1981). In the fundamental level of tax rate causes to increase the tax revenue and after a certain level, tax rate causes to reduce the tax revenue.

The theoretical background and empirical evidence between tax rate and tax revenue was developed by Laffer (1981). This relationship suggests that at the initial stages an increase in tariff rate is linked with an increase in trade revenue but after a certain level of tariff rate (optimal) further increase in tariff rate may decrease trade revenue. This relationship between tariff rate and trade revenue is termed as Trade Laffer Curve.

\section{Econometric Methodology and Data Sources}

This study employ the autoregressive distributed lag (ARDL) bounds testing method proposed by Pesaran, Shin, and Smith (2001) and after that (Narayan, 2005).The Cointegration analysis (short run and long run equilibrium) has used among trade revenue and trade liberalization plus other supporting explanatory variables. Luckily, ARDL method is more preferable approach as compared to previous. First, this method is more favorable for small sample time period. Second, this approach is more applicable for mix order of integration. Finally, this approach is more suitable for a long run to short run coefficient with simple linear transformation of variables as suggested by (Banerjee, Dolado, \& Mestre, 1998).

Sukkur IBA Journal of Management and Business - SIJMB | Volume 5 No. 1 January - June 2018 @ Sukkur IBA University 
According to previous discussion, previous works review and certain assumptions, we employed the linear and non-linear model as below. The non-linear (inverted U shape) behavior investigates between trade revenue and tariff rate for country specific for Pakistan. Further, see the trade Laffer curve existences in the case of Pakistan with the help of trade tax and trade revenue as mentioned by (Laffer, 1981). For empirical testing, we utilized the following model only for trade revenue affect rather than welfare consequence of trade liberalization.

$$
\mathrm{TR}=\mathrm{f}(\mathrm{GDPC}, \mathrm{ATR}, \mathrm{EXC}, \mathrm{CPI}, \mathrm{TOT}) 4.1
$$

Now, we take natural log on both side for judgment of empirical effect of trade liberalization and trade revenue. We write the estimated equation as follows;

$$
\mathrm{LTR}=\beta_{0}+\beta_{1} \mathrm{LATR}+\beta_{2} \mathrm{LATR}^{2}+\beta_{3} \mathrm{LGDPC}+\beta_{4} \mathrm{LEXC}+\beta_{5} \mathrm{LCPI}+\beta_{6} \mathrm{LTOT}+\mu
$$

Where, TR $=$ Trade tax revenue collect from custom duties on trade goods and services are used as a proxy for trade revenue. $\mathrm{EXC}=$ real effective exchange rate is used by Hisali (2012) and Epaphra (2014) to investigate the impact of trade liberalization on trade revenue. GDPC $=$ Gross Domestic per capita use as level of development as well as consumer demand. GDP per capita is used by Khattry and Rao (2002)as a determinant of trade revenue. $\mathrm{CPI}=$ Measure for domestic price behavior, High prices are assumed to be inversely related with trade tax revenue and vice versa (Hisali, 2012). ATR $=$ Average tariff rate measured as weighted mean of all product percentage is used as a proxy of trade liberalization policy (M. Keen and Ligthart (2002); Stotsky et al., 1999) $\mathrm{ATR}^{2}=$ squared term of average tariff rate is used to capture the non-linear effect of trade liberalization on trade revenue. The data on average tariff rate is taken from Pakistan Customs Tariff annual report various issues (Custom Wing) Federal Board of Revenue, Government of Pakistan. TOT $=$ Terms of trade. The time period is employed 1975 to 2014 for empirical investigation. The major data sources are Handbook of Statistic on Pakistan Economy published by State Bank of Pakistan (2010), Pakistan Economic Survey 2014-15 published by Ministry of Finance, Government of Pakistan and World Development Indicator (WDI) by World Bank (2014).

\section{Empirical Results}

The first step was to investigate the stationarity level of all concerned variables examined through Ng-Perron (2001) among others because this test produced more reliable results for less time span series. Most of the macroeconomics variables have unit root problems. Without identifying the level of stationarity the empirical results are meaningless. Estimated outcomes of unit root tests are reported in Table-5.1 below. The empirical testing shows that variables have different levels of stationarity level. Such as trade openness $\left(\mathrm{LOPE}_{t}\right)$ and GDP per capita $\left(\mathrm{LGDPC}_{\mathrm{t}}\right)$ are stationary at level or order $\mathrm{I}(0)$. Trade revenue $\left(\mathrm{LTR}_{\mathrm{t}}\right)$, Average tariff rate $\left(\mathrm{LATR}_{\mathrm{t}}\right)$, Exchange rate

Sukkur IBA Journal of Management and Business - SIJMB | Volume 5 No. 1 January - June 2018 @ Sukkur IBA University 
Ahmad, K., \& Ali, S. / Trade Liberalization-Trade Revenue Nexus: An Empirical Enquiry of Trade Laffer Curve of

$\left(\mathrm{LEXC}_{\mathrm{t}}\right)$, Term of trade $\left(\mathrm{LTOT}_{t}\right)$ and Domestic prices $\left(\mathrm{LCPI}_{\mathrm{t}}\right)$ are integrated of order one or $\mathrm{I}(1)$.

Table 5.1: Unit Root Results

\begin{tabular}{|c|c|c|c|c|}
\hline \multicolumn{2}{|r|}{1.1} & \multicolumn{3}{|c|}{$\mathrm{Ng}$-Perron at Level } \\
\hline Variables & MZa & $\mathbf{M Z t}$ & MSB & MPT \\
\hline LTRt & 1.5372 & 0.8333 & 0.5420 & 80.3637 \\
\hline LATRt & -7.4289 & -1.9100 & 0.2571 & 12.2984 \\
\hline LEXCt & -2.3016 & -0.9651 & 0.4193 & 34.7309 \\
\hline LGDPCt & $-17.217 * *$ & -2.9046 & 0.1687 & 5.46783 \\
\hline LTOTt & -4.4959 & -1.4110 & 0.3138 & 19.5619 \\
\hline LCPIt & -3.7069 & -1.2178 & 0.3285 & 22.484 \\
\hline \multicolumn{5}{|c|}{$N g$-Perron at $1^{\text {st }}$ Difference } \\
\hline Variables & MZa & $\mathbf{M Z t}$ & MSB & MPT \\
\hline LTRt & $-28.0246^{*}$ & -3.7257 & 0.1329 & 3.3528 \\
\hline LATRt & $-20.8502 * *$ & -3.1967 & 0.1533 & 4.5618 \\
\hline LEXCt & $-14.4175^{* * *}$ & -2.6471 & 0.1836 & 6.5371 \\
\hline LGDPCt & $-15.4103 * * *$ & -2.7540 & 0.1787 & 6.0405 \\
\hline LTOTt & $-22.6434 *$ & -3.3578 & 0.1482 & 4.0657 \\
\hline LCPIt & $-15.0214 * *$ & -2.7212 & 0.18116 & 6.17896 \\
\hline
\end{tabular}

$*, * *, * * *$ shows the $1 \%, 5 \%, 10 \%$ level of significant

The estimated result of the test indicates that the variables have mixed order of stationarity or integration. When variables have different order of integration it does not permit us to apply the traditional approaches to co-integration. These results justify our method to apply ARDL approach of co-integration. Schwarz information is used to optimal lag selection the results are present in Table-5.2.

Table 5.2: Lag Selection Criteria

\begin{tabular}{cccccc}
\hline Lags & $\begin{array}{c}\text { Sequential } \\
\text { modified }\end{array}$ & $\begin{array}{c}\text { Final } \\
\text { prediction }\end{array}$ & $\begin{array}{c}\text { Akaike } \\
\text { information }\end{array}$ & $\begin{array}{c}\text { Schwarz } \\
\text { information }\end{array}$ & Hannan-Quinn \\
\hline 0 & -40.836 & NA & 6.897 & 2.8386 & 3.110 \\
1 & 167.58 & $328.42^{*}$ & $2.071^{*}$ & $-7.610^{*}$ & $-5.706^{*}$ \\
2 & 202.25 & 42.032 & 2.831 & -7.5307 & -3.993 \\
\hline
\end{tabular}


* indicates optimal lag order selected by the criterion

$$
\begin{gathered}
\frac{\text { Sensitivity Analysis }}{\text { Test }=1.5188(0.2584)} \\
\text { ARCH Test }=0.3683(0.516) \\
\text { Heteroscedisticity Test }=1.3250(0.3021) \\
\text { Ramsey Test }=0.2849(0.6242) \\
\text { Normality J-B Value }=0.0890(0.9426)
\end{gathered}
$$

The results of table 5.3 display the bounds testing approach to co-integration estimation confirm that the calculated F-statistics is 6.977 and it is higher than the upper critical bound as suggested by Pesaran et al. (2001) and Narayan (2005) at 5\% level of significance. It is established that there is a long run cointegration exists among the variables because significant F-statistics. The next step is to investigate the long run elasticity of coefficients.

The next step is to find out the long run estimates for variables. The empirical results are reported in Table 5.4. The estimated coefficient tells us that tariff rate is positively associated with trade revenue. A 0.030 percent trade revenue is improved by 1 percent increase in average tariff rate. The link is statistically significant at 1 percent. Our estimated coefficient elasticity seems to support (Stotsky et al., 1999) and (Khattry \& Rao, 2002). It means that trade liberalization produces adverse impact on trade tax revenue. In the light of results country improves the tariff rate to collect trade revenue because trade tax revenue has less cost of tax collection as well as low welfare loss. The elasticity of import, income, substitution and exchange rate, the results show that our imports are less price elastic and more income elastic. It means that tariff has adverse impact on trade tax revenue. The results support that Pakistan relies heavily on trade revenue taxation for government revenue. GDP per capita affects trade revenue positively. Elasticity coefficient shows that a .049 percent increase in trade revenue is caused by 1 percent increase in GDP per capita. The empirical result supports the argument developed by (Tanzi, 1989). Higher GDP per capita growth has positive impact on consumer demand for goods and services. Higher consumer demand may improve the share of imports demand in the country.

Per capita has highly significant positive effect on trade tax revenue in Pakistan. The association between trade tax and GDP per capita is positive. The estimates predicated that a 1 percent positive change in per capita GDP as s results of .0495 percent increase in trade tax revenue. Per capita or growth of per capita capture the effects of consumer demand. As the consumer demand increases, it may leads to increase the volume of imports especially in developing countries. So, the per capita has positive impact on imports demand as well as trade revenue. As we established the relationship between exchange rate and trade tax revenue. The elasticity of coefficient indicate that trade tax

Sukkur IBA Journal of Management and Business - SIJMB | Volume 5 No. 1 January - June 2018 @ Sukkur IBA University 
revenue in Pakistan is adversely related. A 1 percent change accord in exchange rate cause to 0.323 percent reduction in trade tax revenue and this association is statistically significant. These results supports the economic theory because when local currency depreciate against foreign currency this may lead to hurt the domestic consumer imports demand in the long run. The depreciation of official has so many economic implications but trade revenue has also one of them. In case of Pakistan the rapid depreciation has been observed during last two decades due to improper monetary arrangement. Consumer prices index has positive impact on trade revenue. The elasticity coefficient shows that a one percent increase in domestic prices will bring 0.08 percent increase in trade revenue. When the domestic prices increase, the import demand will increase which affects the trade revenue positively.

Table 5.3: ARDL Bounds Testing Approach

\begin{tabular}{|c|c|c|c|c|}
\hline \multicolumn{3}{|c|}{ Dependent Variable } & \multicolumn{2}{|c|}{ F-Statistics } \\
\hline \multicolumn{3}{|c|}{$\mathrm{LTR}_{\mathrm{t}}$} & \multicolumn{2}{|c|}{6.9771} \\
\hline & \multicolumn{2}{|c|}{ Pesaran et al $(2001)^{a}$} & \multicolumn{2}{|c|}{ Narayan $(2005)^{b}$} \\
\hline Critical Value & $\begin{array}{c}\text { Lower } \\
\text { Bound } \\
\text { Value }\end{array}$ & $\begin{array}{c}\text { Upper } \\
\text { Bound } \\
\text { Value } \\
\end{array}$ & $\begin{array}{l}\text { Lower } \\
\text { Bound } \\
\text { Value }\end{array}$ & $\begin{array}{l}\text { Upper } \\
\text { Bound } \\
\text { Value }\end{array}$ \\
\hline $1 \%$ & 5.15 & 6.36 & 6.140 & 7.607 \\
\hline $5 \%$ & 3.79 & 4.85 & 4.183 & 5.333 \\
\hline $10 \%$ & 3.17 & 4.14 & 3.393 & 4.410 \\
\hline
\end{tabular}

a, The estimated model based on unrestricted intercept and no time trend obtained from Pesaran et al (2001), ${ }^{\mathrm{b}}$ Critical bounds obtained from Narayan (2005) on the basses of unrestricted intercept and no trend.

The empirical results of inverted-U-shaped behavior of trade laffer curve behaviour observed in the second model. The calculated results tell us that average tariff rate is positively linked with trade revenue in linear term in the long run. The estimated coefficient shows that 0.08 percent trade revenue is improved by 1 percent change in average tariff rate. The estimated coefficient is statistically significant at 1 percent level significant. While, non-linear term of average tariff rate is inversely related with trade revenue significantly. The estimated coefficient shows that a 1 percent change accord in square term of tariff rate causes -0.01 percent reduce trade revenue in Pakistan. When close economy is liberalized the trade or reducing the tariff rate is cause to surges revenue from trade openness. More liberalized economy is lowering tariff rate on trade causes to reduce revenue from trade. Overall our results seem to support (Stotsky et al., 1999) and (Khattry \& Rao, 2002).

Sukkur IBA Journal of Management and Business - SIJMB | Volume 5 No. 1 January - June 2018 @ Sukkur IBA University 
Table 5.4: Long Run Results

\begin{tabular}{|c|c|c|c|c|}
\hline \multicolumn{5}{|c|}{ Dependent Variable $=$ LTR $_{t}$} \\
\hline Variables & Coefficient & Prob. Value & Coefficient & Prob. Value \\
\hline Constant & -0.8949 & 0.0000 & -0.8201 & 0.0067 \\
\hline LATR $_{t}$ & 0.0309 & 0.0000 & 0.0800 & 0.0085 \\
\hline $\mathrm{LATR}_{\mathrm{t}}^{2}$ & --- & --- & -0.0102 & 0.0530 \\
\hline $\mathrm{LGDPC}_{\mathrm{t}}$ & 0.0495 & 0.0074 & 0.7733 & 0.5437 \\
\hline $\mathrm{LEXC}_{t}$ & -0.3237 & 0.0954 & -0.1766 & 0.4552 \\
\hline $\mathrm{LCPI}_{\mathrm{t}}$ & 0.0871 & 0.0000 & 0.0984 & 0.0000 \\
\hline $\mathrm{LTOT}_{\mathrm{t}}$ & --- & ---- & 0.1907 & 0.2398 \\
\hline \multicolumn{3}{|c|}{$R$-squared $=0.9877$} & \multicolumn{2}{|c|}{$R$-squared $=0.9896$} \\
\hline \multirow{2}{*}{\multicolumn{3}{|c|}{$\begin{array}{c}\text { Adjusted } R \text {-squared }=0.9854 \\
F \text {-statistic }=419.7558\end{array}$}} & \multicolumn{2}{|c|}{ Adjusted $R$-squared $=0.9871$} \\
\hline & & & \multicolumn{2}{|c|}{$F$-statistic $=399.9417$} \\
\hline \multicolumn{3}{|c|}{ Durbin-Watson $=1.5203$} & \multirow{2}{*}{\multicolumn{2}{|c|}{$\begin{array}{c}\text { Durbin } \text {-Watson }=1.7018 \\
\operatorname{Prob}(F-\text { statistic })=0.0000\end{array}$}} \\
\hline \multicolumn{3}{|c|}{$\operatorname{Prob}(F$-statistic $)=0.0000$} & & \\
\hline
\end{tabular}

This effect is demonstrated by a "Trade Laffer Curve" that explains the relationship between tariff rates and trade revenue. When tariff rate is high, it reduces the trade tax revenue due to reduction in imports volume. On the contrary, the lower tariff rate may also reduce the tax revenue from trade openness. Pakistan has already relatively liberalized its border, additional discounts in tariff rate will not be the source of any addition in trade revenue.

Table 5.5: Short Run results

\begin{tabular}{|c|c|c|c|c|}
\hline \multicolumn{5}{|c|}{ Dependent Variable $=\Delta \mathrm{LTR}_{\mathrm{t}}$} \\
\hline Variables & Coefficient & Prob. Value & Coefficient & Prob. Value \\
\hline Constant & -0.3221 & 0.1470 & -0.2102 & 0.0531 \\
\hline$\Delta \mathrm{LATR}_{\mathrm{t}}$ & 0.0345 & 0.0829 & 0.0517 & 0.0327 \\
\hline$\Delta \mathrm{LATR}_{\mathrm{t}}^{2}$ & --- & ---- & 0.1021 & 0.0512 \\
\hline$\Delta \mathrm{LGDPC}_{\mathrm{t}}$ & 0.0477 & 0.0263 & 0.0326 & 0.0001 \\
\hline$\Delta \mathrm{LEXC}_{\mathrm{t}}$ & -0.0237 & 0.4235 & -0.2410 & 0.2047 \\
\hline$\Delta \mathrm{LCPI}_{\mathrm{t}}$ & 0.0537 & 0.0000 & 0.2210 & 0.2399 \\
\hline$\Delta \mathrm{LTOT}_{\mathrm{t}}$ & --- & ---- & 0.2020 & 0.0131 \\
\hline $\mathrm{ECT}_{\mathrm{t}-1}$ & -0.2948 & 0.0429 & -13813 & 0.0106 \\
\hline \multicolumn{3}{|c|}{ R-squared $=0.8400$} & \multicolumn{2}{|c|}{ R-squared $=0.8296$} \\
\hline \multicolumn{3}{|c|}{ Adjusted R-squared $=0.8220$} & \multicolumn{2}{|c|}{ Adjusted R-squared $=0.8117$} \\
\hline \multicolumn{3}{|c|}{ F-statistic $=33.3340$} & \multicolumn{2}{|c|}{ F-statistic $=99.9417$} \\
\hline \multicolumn{3}{|c|}{$\operatorname{Prob}($ F-statistic $)=0.0191$} & \multicolumn{2}{|c|}{$\operatorname{Prob}($ F-statistic $)=0.0000$} \\
\hline \multicolumn{3}{|c|}{ Durbin-Watson $=1.6192$} & \multicolumn{2}{|c|}{ Durbin-Watson $=1.7018$} \\
\hline
\end{tabular}

Sukkur IBA Journal of Management and Business - SIJMB | Volume 5 No. 1 January - June 2018 @ Sukkur IBA University 
Table-5.5 presents the results of short run behavior of trade revenue variables and trade tax. The trade revenue is positively associated with average tariff rate. A 1 percent increase in tariff rate replies to raise trade revenue by 0.030 percent. Average tariff rate is positively linked with trade revenue in square term of average tariff rate in short run. A one percent increase square average tariff rate will bring .101 percent positive change in trade revenue. The above results show that Pakistan improves tariff rate for more trade revenue in short run in the incidences of less welfare loss. The $U$ shaped behavior of trade liberalization and trade tax revenue do not exist in short run.

In short run, GDP Per capita has highly significant positive effect on trade tax revenue in Pakistan. The association between trade tax and GDP per capita is positive. The estimates predicated that a 1 percent positive change in per capita GDP as s results of .0477 percent increase in trade tax revenue. Per capita or growth of per capita capture the effects of consumer demand. As we established the relationship between exchange rate and trade tax revenue. The elasticity of coefficient indicates that trade tax revenue in Pakistan is adversely related. A 1 percent change accord in exchange rate causes 0.0237 percent reduction in trade tax revenue and this association is statistically insignificant. . Consumer prices index has positive impact on trade revenue for short span of time. The elasticity coefficient shows that a one percent increase in domestic prices will bring 0.0537 percent increase in trade revenue. When the domestic prices increase, the import demand will increase which affects the trade revenue positively.

Short-run estimates are presented in table-5.5. The coefficient of lagged error correction term i.e.EC $\mathrm{E}_{\mathrm{t}-1}$ shows the speed of adjustment towards long run equilibrium. The sign of $\mathrm{EC}_{\mathrm{t}-1}$ is negative and statistically significant at five percent. The coefficient of $\mathrm{EC}_{\mathrm{t}-1}$ is equal to -0.294 and it is significant at 5 percent level of significance. Furthermore, coefficient of $\mathrm{EC}_{\mathrm{t}-1}$ suggests that in case of economic shocks, the long run equilibrium will be reestablished with the speed of 29.40 percent per year.

\section{Conclusion}

The main purpose of this study is to discover the fiscal implication of trade liberalization and trade revenue. Laffer curve approach is used to see the non-linear relationship between trade revenue and trade liberalization in case of Pakistan. ARDL testing is used to instigate the empirical investigation for time series data. The empirical results show that trade liberalization has positive impact on trade revenue in linear term. Average tariff rate significantly increases trade tax revenue because our trade items are less price elastic in nature in short run. GDP Per capita and inflation rate also promote trade tax revenue in the long run because more income surge the foreign imports demand.

Trade revenue is positively related with tariff rate in linear term, while average tariff rate is negatively related with trade revenue in non- linear term. Our empirical evidence

Sukkur IBA Journal of Management and Business - SIJMB | Volume 5 No. 1 January - June 2018 @ Sukkur IBA University 
confirms the existence of Trade Laffer curve behavior in Pakistan in the long run but not in the short run. Pakistan has already relatively liberalized its border, additional discounts in tariff rate will not be the source of any addition in trade revenue. Furthermore, the result indicates that there is reverse association between exchange rate and trade revenue both in short and long run. As high inflation in domestic economy leads towards depreciation of local currency and against foreign exchange rate. Therefore, the inflation targeting through effective monetary arrangements can help improve the trade revenue in the future. For policy formulation Pakistan should increase the average tariff rate for trade revenue generation in the short run, because, less import demand behavior causes more trade revenue with less welfare loss.

\section{References}

Adam, C. S., Bevan, D. L., \& Chambas, G. (2001). Exchange rate regimes and revenue performance in Sub-Saharan Africa. Journal of development economics, 64(1), 173-213.

Agbeyegbe, T. D., Stotsky, J., \& WoldeMariam, A. (2006). Trade liberalization, exchange rate changes, and tax revenue in Sub-Saharan Africa. Journal of Asian Economics, 17(2), 261-284.

Ahmad,K. A, R Chaudhary. (2016). Trade Liberalization, Fiscal Performance And Economic Growth: An Empirical Analysis for Pakistan (2012). Unpublished $\mathrm{PhD}$. Thesis, Faculty of Social, NCBA\&E, Lahore Pakistan.

Aizenman, J., \& Jinjarak, Y. (2009). Globalisation and developing countries-a shrinking tax base? The Journal of Development Studies, 45(5), 653-671.

Anderson, J. E. (1998). Trade restrictiveness benchmarks. The Economic Journal, 108(449), 1111-1125.

Aliyu, S. R. (2001). Trade Liberalization and Economic Growth in Nigeria: 1970 1998. Unpublished PhD. Thesis, Faculty of Social and Management Sciences, Bayero University Kano; Nigeria.

Bacha, E. L. (1990). A three-gap model of foreign transfers and the GDP growth rate in developing countries. Journal of Development economics, 32(2), 279-296.

Banerjee, A., Dolado, J., \& Mestre, R. (1998). Error-Correction Mechanism Tests for Cointegration in a Single-Equation Framework. Journal of time series analysis, 19(3), 267-283.

Bevan, M. D. (1995). Fiscal Implications of Trade Liberalization: International Monetary Fund.

Bhagwati, J. (2004). Anti-globalization: why? Journal of Policy Modeling, 26(4), 439463.

Bhagwati, J. N. (2004). In Defense of Globalization: It Has a Human Face. Rivista di Politica Economica, 94(6), 9.20.

Edwards, S. (1992). Trade Orientation, Distortions and Growth in Developing Countries. Journal of development economics, 39(1), 31-57.

Sukkur IBA Journal of Management and Business - SIJMB | Volume 5 No. 1 January - June 2018 @ Sukkur IBA University 
Emran, M. S. (2005). Revenue-increasing and Welfare-enhancing Reform of Taxes on Exports. Journal of development economics, 77(1), 277-292.

Epaphra, M. (2014). The Revenue Implications of Trade Liberalization in Tanzania. World Economic Research, 3(10), 25-36.

Feenstra, R. C. (2015). Advanced international trade: theory and evidence: Princeton university press.

Haque, M. E., \& Mukherjee, A. (2005). On the revenue implications of trade liberalization under imperfect competition. Economics Letters, 88(1), 27-31.

Hisali, E. (2012). Trade Policy Reform and International Trade Tax Revenue in Uganda. Economic Modelling, 29(6), 2144-2154.

Kenen, P. B. (1985). Macroeconomic Theory and Policy: How the Closed Economy Model was Opened. in R. Jones and P. Kenen (eds.), Handbook of International Economics, Vol. 2, Amsterdam, North-Hollan, 625-77.

Keen, M., \& Ligthart, J. E. (2002). Coordinating Tariff Reduction and Domestic Tax Reform. Journal of International Economics, 56(2), 489-507.

Keen, M., \& Ligthart, J. E. (2005). Coordinating Tariff Reduction and Domestic Tax Reform under Imperfect Competition. Review of International Economics, 13(2), 385-390.

Keen, M. M., \& Baunsgaard, M. T. (2005). Tax revenue and (or?) trade liberalization: International Monetary Fund.

Khattry, B., \& Rao, J. M. (2002). Fiscal Faux Pas?: an Analysis of the Revenue Implications of Trade Liberalization. World Development, 30(8), 1431-1444.

Kowalski, P. (2005). Impact of changes in tariffs on developing countries' government revenue. OECD Trade Policy Papers, No. 18, OECD Publishing, Paris.

Krueger, A. O. (1997). Trade policy and economic development: how we learn: National Bureau of Economic Research.

Krugman, P. R. (1986). Strategic Trade Policy and the New International Economics: MIT Press.

Laffer, A. B. (1981). Government Exactions and Revenue Deficiencies. The Cato Journal. 1, 1-21.

Melvin, J. R. (1970). Commodity taxation as a determinant of trade. The Canadian Journal of Economics, 3(1), 62-78.

Melvin, J. R. (1975). The tax Structure and Canadian Trade: A Theoretical Analysis: Economic Council of Canada. Ottawa

Mill, J. S. (1848). The Collected Works of John Stuart Mill, Volume II: The Principles of Political Economy with Some of Their Applications to Social Philosophy: Online Library of Liberty.

Mujumdar, S. (2004). Revenue Implications of Trade Liberalization under Imperfect Competition. Economics Letters, 82(1), 83-89.

Naito, T. (2006). Tariff and Tax Reform: Dynamic Implications. Journal of International Economics, 68(2), 504-517.

Sukkur IBA Journal of Management and Business - SIJMB | Volume 5 No. 1 January - June 2018 @ Sukkur IBA University 
Narayan, P. K. (2005). The Saving and Investment Nexus for China: Evidence from Cointegration Tests. Applied economics, 37(17), 1979-1990.

Negishi, T. (1972). General Equilibrium Theory and International Trade. NorthHolland Publishing Company. Amsterdam.

Ng, S., \& Perron, P. (2001). Lag Length Selection and the Construction of Unit Root Tests with Good Size and Power. Econometrica, 69(6), 1519-1554.

Pesaran, M. H., Shin, Y., \& Smith, R. J. (2001). Bounds Testing Approaches to the Analysis of Level Relationships. Journal of Applied Econometrics, 16(3), 289326.

Pupongsak, S. (2010). The effect of trade liberalization on taxation and government revenue. University of Birmingham.

Rajaram, A. (1992). Tariff and tax reform: do World Bank recommendations integrate revenue and protection objectives? (Vol. 1018). World Bank Publications.

Rodríguez, F., \& Rodrik, D. (2001). Trade Policy and Economic Growth: a skeptic's guide to the cross-national evidence. Bernanke, B., Rogoff, KS Macroeconomics Annual 2000: Cambridge, MA: MIT Press.

Salvatore, D. (2013). International economics: John Wiley \& Sons Hoboken, NJ.

Spearot, A. C. (2013). Variable Demand Elasticities and Tariff Liberalization. Journal of International Economics, 89(1), 26-41.

Stotsky, M. J. G., Ebrill, M. L. P., \& Gropp, M. R. (1999). Revenue Implications of Trade Liberalization: International Monetary Fund.

Tanzi, V. (1989). The Impact of Macroeconomic Policies on the Level of Taxation and the Fiscal Balance in Developing Countries. Staff Papers, 36(3), 633-656.

Yap, J. T. (1997). Macroeconomic Impact of a Tariff Reduction: a three-gap analysis with model simulations: Philippine Institute for Development Studies.

Zaidi, S. A. (2005). Issues in Pakistan's economy. OUP Catalogue.

Sukkur IBA Journal of Management and Business - SIJMB | Volume 5 No. 1 January - June 2018 @ Sukkur IBA University 